\title{
HEALTH GEOGRAPHY IN CASE OF ZASAVJE: LINKING OF ATMOSPHERIC AIR POLLUTION AND RESPIRATORY DISEASES DATA
}

\section{GEOGRAFIJA ZDRAVJA NA PRIMERU ZASAVJA: POVEZOVANJE PODATKOV O ONESNAZENOSTI OZRAČJA IN BOLEZNIH DIHAL}

Andreja Kukec, Lijana Zaletel - Kragelj, Jerneja Farkaš - Lainščak, Ivan Eržen, Andrej Herakovič, Marija Zlata Božnar, Primož Mlakar, Boštjan Grašič in Vesna Zadnik

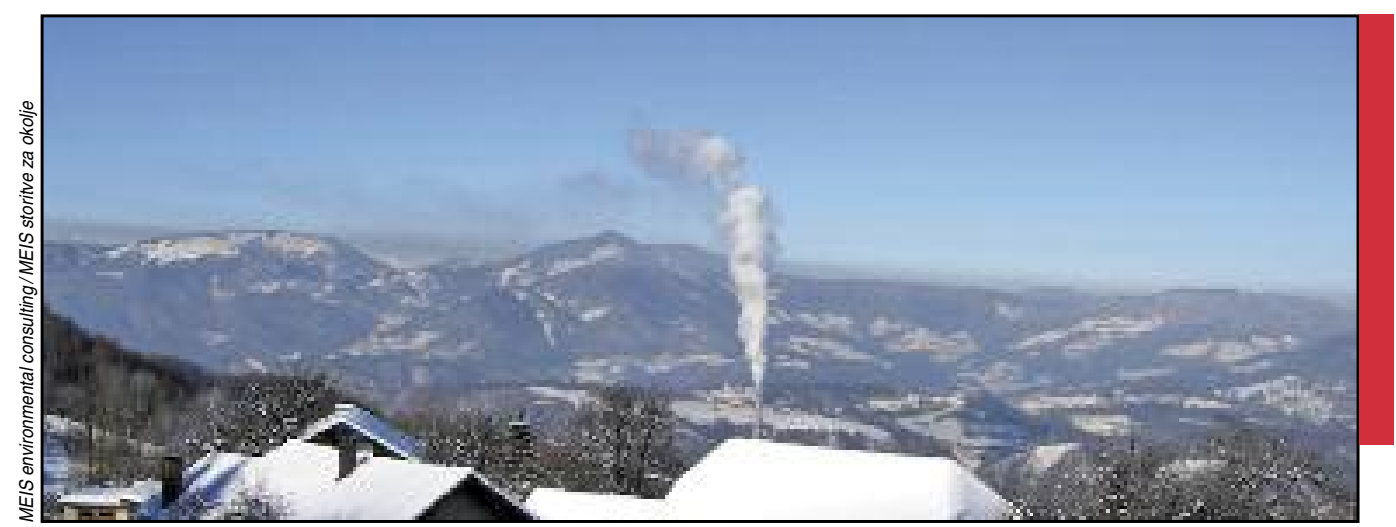

Complex terrain in the Zasavje region. Razgibanost reliefa v Zasavju. 


\section{Health geography in case of Zasavje: Linking of atmospheric air pollution and respiratory diseases data}

DOI: http://dx.doi.org/10.3986/AGS54208

UDC: 91:613(497.432)

504.5:502.3:616.2(497.432)

COBISS: 1.01

\section{ABSTRACT:}

The aim of the study was to assess the association between atmospheric air pollution and respiratory diseases in children on the level of small spatial units in the Zasavje. The health and environmental data were obtained for the period between January 1 and December 31,2011. Studied small spatial units were designed on the basis of estimated level of atmospheric air pollution and digital maps and boundaries of local communities and settlements. The impact of atmospheric air pollution on respiratory diseases was analysed by using the Bayesian models. Considering the identified deficiencies, the presented methodolgy can often be used to identify areas with a higher health risks.

KEY WORDS: studied small spatial units, respiratory diseases, children, atmospheric air pollution, spatial smoothing, Zasavje

The article was submitted for publication on January 31, 2013.

\section{ADDRESSES:}

\section{Andreja Kukec}

University of Ljubljana, Faculty of Medicine

Public Health Centre

Zaloška ulica 4, SI - 1000 Ljubljana, Slovenia

E-mail: andreja.kukec@mf.uni-lj.si

Lijana Zaletel - Kragelj, Ph. D.

University of Ljubljana, Faculty of Medicine

Public Health Centre

Zaloška ulica 4, SI - 1000 Ljubljana, Slovenia

E-mail: lijana.kragelj@mf.uni-lj.si

Jerneja Farkaš - Lainščak, Ph. D.

University of Ljubljana, Faculty of Medicine

Public Health Centre

Zaloška ulica 4, SI - 1000 Ljubljana, Slovenia

E-mail: jerneja.farkas@mf.uni-lj.si

Ivan Eržen, Ph. D.

University of Ljubljana, Faculty of Medicine

Public Health Centre

Zaloška ulica 4, SI - 1000 Ljubljana, Slovenia

E-mail: ivan.erzen@mf.uni-lj.si

\section{Andrej Herakovič}

Municipality of Škocjan

Škocjan 67, SI - 8275 Škocjan, Slovenia

E-mail: andrej.herakovic@obcina-skocjan.si 
Marija Zlata - Božnar, Ph. D.

MEIS environmental consulting

Mali Vrh pri Šmarju 78, SI - 1293 Šmarje-Sap, Slovenia

E-mail: marija.zlata.boznar@meis.si

\section{Primož Mlakar, Ph. D.}

MEIS environmental consulting

Mali Vrh pri Šmarju 78, SI - 1293 Šmarje-Sap, Slovenija

E-mail: primoz.mlakar @meis.si

\section{Boštjan Grašič, Ph. D.}

MEIS environmental consulting

Mali Vrh pri Šmarju 78, SI - 1293 Šmarje-Sap, Slovenija

E-mail: bostjan.grasic@meis.si

\section{Vesna Zadnik, Ph. D.}

Epidemiology and cancer register

Institute of Oncology Ljubljana

Zaloška cesta 2, SI - 1000 Ljubljana, Slovenija

E-mail:vzadnik@onko-i.si 


\section{Introduction}

The presence and perception of risk factors in the natural and social environment, and their impact on health have placed increasing importance on health geography - in particular, spatial epidemiology (Zadnik 2006; Staut 2008). The World Health Organization (WHO) has also drawn attention to its applicability in evaluating and managing risk factors (Briggs et al. 1996).

The impact of environmental risks is relatively complex and therefore, when analyzing their correlation with health phenomena, it is necessary to combine the methods of public health and geographic information systems (GIS) (WHO 1999; Rytkönen 2004; Vudrag \& Boštjančič 2007; Beale et al. 2008; Dummer 2008; Staut 2008; Erlih \& Eržen 2010). With these methods it is possible to identify areas with greater or lesser risk for the development of health issues and present them in the form of disease maps (Zadnik 2006).

An important methodological question in spatial epidemiology is which and what size of spatial units should be used as the basic units of study. Initially larger spatial units were used, but with the development of spatial epidemiology methods and techniques smaller ones began to be used (Stroh et al. 2007). Small spatial units have a number of advantages over large ones. Selecting a smaller basic spatial unit for analysis increases the resolution, thus retaining information on heterogeneity, which is lost in large spatial units. However, problems also exist with using small spatial units. In particular, reducing the area of study yields an increasingly smaller number of sampled units to be used for calculating the health indicators for individual spatial units, which lowers the level of confidence in them (Zadnik 2006; Zadnik \& Reich 2006). However, the confidence can be increased. The study period can be extended, thus increasing the number of basic units to be used for calculating the health indicators. The development of spatial epidemiology has also introduced spatial smoothing techniques, which use real-life data and additional information to evaluate the value of an indicator for a studied health outcome in individual spatial units examined (Zadnik 2006).

This study evaluates the correlation between air pollution and respiratory diseases in children at the level of small spatial units in the Central Sava Region (Sln. Zasavje). The goal was to evaluate the incidence of respiratory diseases in children and its correlation with air pollution in small spatial units of study. A second goal was to evaluate the advantages and disadvantages of this type of correlation.

\section{Methods}

\subsection{Research design}

This study was part of a larger project carried out from 1 January 2006 to 31 December 2011 by the Department of Public Health at the University of Ljubljana's Medical School, in which healthcare and environmental specialists also participated. In terms of its design, the first part of the study examines the spatial patterns of environmental and health phenomena, and the second part focuses on spatial variability (Morgenstern \& Thomas 1993; Thomas 2009).

\subsection{Research population and period}

The research population consisted of one to eleven-year-old children that lived in one of the three municipalities in the Central Sava Region (Zagorje ob Savi, Trbovlje, and Hrastnik) during the research period and were treated for respiratory diseases at one of the local health centers between 1 January 2011 and 31 December 2011.

\subsection{Study area}

Small spatial units of study were defined and used as the model study area. Separate small spatial units of study were developed for each pollutant studied: dust particles $\left(\mathrm{PM}_{10 \text { winter average }}, \mathrm{PM}_{10 \text { summer average }}\right)$, sulfur dioxide $\left(\mathrm{SO}_{2 \_ \text {annual average }}\right)$, and nitrogen dioxide $\left(\mathrm{NO}_{2 \_ \text {annual average }}\right)$ (Kukec et al. 2012). 


\subsection{Defining small spatial units of study}

Small spatial units of study were defined using the evaluated level of air pollution and digital maps of local communities and settlements in the municipalities of the Central Sava Region. Dispersion models with input emission values of point sources of pollution, meteorological data, and data on the volume of vehicle traffic and use of home furnaces were used to evaluate the level of air pollution. In order to forecast and diagnose the air pollution, we used the Weather Research and Forecasting (WRF) model to develop our own weather forecast. The SurfPro meteorological interface processor and the Swift mass-consistent $3 \mathrm{D}$ wind model were used to calculate the approximation of 3D wind, temperature, and turbulence fields. The numerical Lagrangian particle dispersion model SPRAY with Monte Carlo simulation was used to calculate the pollution spread. The ArcGIS tool was used to develop small spatial units of study (MEIS, 2012; Kukec et al. 2012).

\subsection{Origin and georeferencing of health data}

The health data were obtained from the information system used by the health centers in the Central Sava Region. Selected diagnoses of respiratory diseases were studied following the tenth revision of the International Classification of Diseases (ICD-10; WHO 2011).

Authorized staff at the health center conveyed the following information: the identification code of the visit, date of visit, type of visit, diagnosis, date of birth, sex, and permanent address.

The permanent address data were georeferenced: each address was assigned a geographical coordinate using the code list of the Spatial Units Register, and the point data underwent retrograde aggregation into the designated spatial units (Kukec et al. 2012).

\subsection{Spatial distribution of respiratory diseases cases}

The number of ill children in an individual small unit of study was compared with the anticipated number of ill children based on the number of children below the age of eleven that lived in this unit in 2011 according to the Central Registry of Population and based on the incidence rate in the entire study area (Equation 1). The quotient between the studied and anticipated number of ill children is called the standardized incidence ratio (SIR) and is an approximation of the relative disease risk in this unit (Dos Santos Silva 1999).

$$
S I R=\frac{O}{E}=\frac{O}{\frac{\sum n \cdot R}{\sum n}}
$$

SIR $=$ Standardized incidence ratio

$O=N u m b e r$ of children below eleven that fell ill in the spatial unit studied

$E=$ Anticipated number of ill children in the spatial unit studied

$n=$ Number of children below eleven in the research population

$R=$ Number of children below eleven that fell ill per 100,000 in the entire area

Because the number of spatial units studied is relatively large or because relatively few children that might fall ill live in an individual unit, the influence of coincidence on the value of the SIRs calculated is relatively high. In order to reduce the impact of such a coincidence, the Bayesian hierarchical models for spatial smoothing are used in the spatial analysis of epidemiological data (Elliott et al. 2000). Bayesian hierarchical models with an adapted Poisson regression equation (Equation 2 ) are used to estimate the value of the illness burden indicator for an individual spatial unit studied based on aggregating real data with additional information that may already be known or may involve only random effects. The additional known information included in the analysis consisted of the respiratory disease incidence in children in the neighboring areas and the average respiratory disease incidence in children in the entire study area. Random effects were divided into spatially independent and dependent variables. Spatially dependent variables were assigned a conditional autoregressive (CAR) prior probability distribution that covers all of the data on the geographical structure of the study area. 


$$
S I R^{*}=a+\beta X+H+S
$$

Equation 2

$S I R^{*}=$ Estimated standardized incidence ratio

$a=$ Basic (logarithmized) relative disease risk in the entire study area

$\beta=$ Regression coefficient of the explanatory variable

$X=$ Explanatory variable values

$H=$ Spatially independent random effect

$S=$ Spatially dependent random effect

\subsection{Identifying the impact of air pollution on the incidence of respiratory diseases}

In order to identify the impact of air pollution on the incidence of respiratory diseases, data for every pollutant studied were added to the basic Bayesian model (Equation 2). The basic model was compared to the extended one to determine whether the extended model fitted our data better. The Deviation Information Criterion (DIC), which also sums up the fit and complexity of a model, was used; the smaller the DIC, the greater the predictive power of the model (Elliott et al. 2000).

\subsection{Presenting the spatial distribution of health risks}

Color-scale maps were used to graphically present the empirical and estimated SIRs. Areas with low risks were depicted in blue and those with high risks were depicted in red. The maps were created using the ArcGIS tool. The spatial distribution of the correlation between respiratory diseases in children and air pollution was estimated visually, and the statistical parameter "fraction of individual variable's spatial variability" $\left(\mathrm{Frac}_{\mathrm{Spatial}}\right)$ was used to numerically determine the spatial structure. If the value of the spatial variability fraction was close to 1 , this meant that a spatially dependent random effect predominated. If the value was close to 0, a spatially independent random effect predominated (Eitan et al. 2010).

\section{Results}

\subsection{Spatial distribution of standardized incidence ratio of respiratory diseases}

The spatial distribution of the respiratory disease SIR by small spatial units of study and selected pollutant is presented in Figure 1. The winter and summer averages are presented for $\mathrm{PM}_{10}$, and the annual averages are presented for $\mathrm{SO}_{2}$ and $\mathrm{NO}_{2}$. Great differences in respiratory disease risks can be observed in the neighboring geographical units.

Table 1: Statistical parameters of the basic Bayesian spatial smoothing hierarchical model (CAR) and the model with air pollution included (CAR-X), showing a correlation between respiratory diseases in children and pollutants by spatial units studied, 2011.

\begin{tabular}{llccc}
\hline Pollutants & Model & $\begin{array}{c}\text { Deviation information } \\
\text { criterion }\end{array}$ & $\begin{array}{c}\text { Fraction of spatial } \\
\text { variability }\end{array}$ & $\begin{array}{c}\text { Regression coefficient } \\
(95 \% \text { confidence interval })\end{array}$ \\
\hline $\mathrm{PM}_{10}$ winter $\left(\mu \mathrm{g} / \mathrm{m}^{3}\right)$ & CAR & 445.50 & 0.093 & \\
& CAR-X & 446.20 & 0.109 & $0.07(-0.03 ; 0.18)$ \\
\hline $\mathrm{PM}_{10}$ summer $\left(\mu \mathrm{g} / \mathrm{m}^{3}\right)$ & CAR & 378.39 & 0.778 & $-0.04(-0.19 ; 0.11)$ \\
& CAR-X & 380.43 & 0.789 & \\
\hline $\mathrm{SO}_{2}\left(\mu \mathrm{g} / \mathrm{m}^{3}\right)$ & CAR & 405.00 & 0.570 & $\mathbf{0 . 2 4}(\mathbf{0 . 0 1} ; \mathbf{0 . 5 1})$ \\
& CAR-X & 406.78 & 0.657 & $0.05(-0.05 ; 0.16)$ \\
\hline $\mathrm{NO}_{2}\left(\mu \mathrm{g} / \mathrm{m}^{3}\right)$ & CAR & 460.29 & 0.310 & \\
& CAR-X & 457.13 & 0.322 & \\
\hline
\end{tabular}

Legend: $C A R=$ conditional autoregressive prior probability distribution 


\subsection{Spatial distribution of smoothed standardized incidence ratio of respiratory diseases}

Figure 2 presents the spatial distribution of estimated incidence risks prepared through spatial smoothing in the Bayesian hierarchical model by taking into account the incidence risk in the population of the entire study area and the risk in the neighboring areas by specified spatial units and selected pollutant. The differences between individual neighboring geographical units are significantly smaller. The most important statistical parameters of the models are summarized in Table 1. A spatial pattern in the distribution of the health outcome studied is evident in the model dealing with $\mathrm{PM}_{10}$ in the summer and $\mathrm{SO}_{2}$.

a) $\mathrm{SIR} / \mathrm{PM}_{10}$ (winter average/zimsko povprečje)

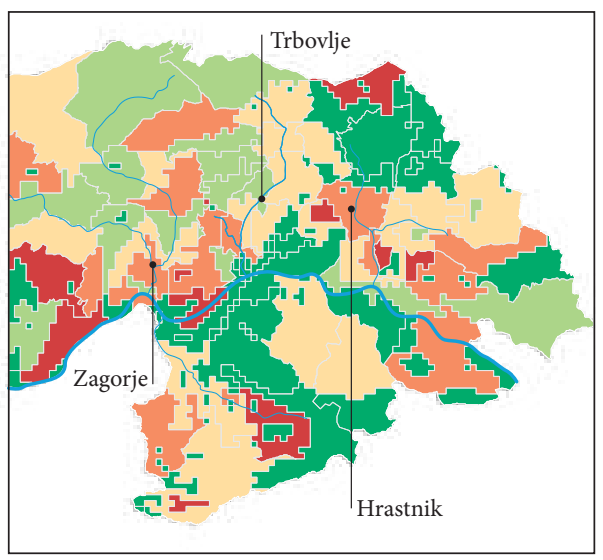

b) $\mathrm{SIR} / \mathrm{SO}_{2}$ (annual average/letno povprečje)

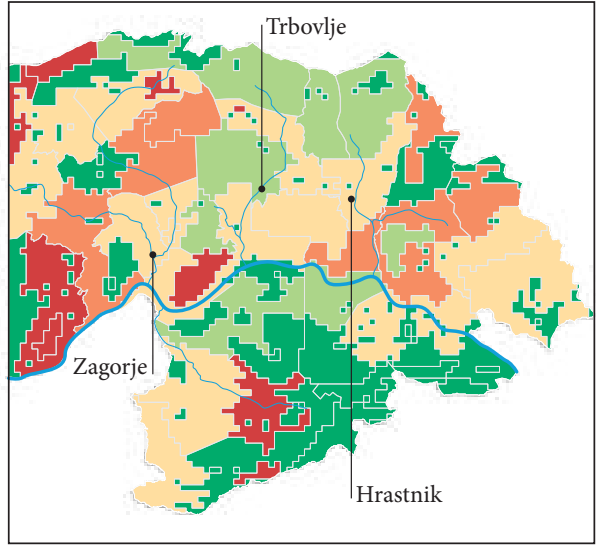

$\square-0.490$

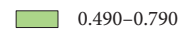

Scale/merilo:

$0 \quad 2.5$

Figure 1: Spatial distribution of the actual incidence rate of respiratory diseases in children by spatial unit studied and selected pollutant, 2011. $\mathrm{SIR}=$ standardized incidence ratio 


\subsection{Statistical models of spatial analysis of correlation between respiratory diseases and air pollution}

The spatial analysis of the correlation between respiratory diseases in children and the selected pollutants is presented in Figure 3, and the most important statistical model parameters are summarized in Table 1. The inclusion of explanatory variables did not significantly improve the model; the fits of the models are comparable for the CAR (Figure 2) and CAR-X (Figure 3) models with all the pollutants. The models show that the differences in pollution between individual areas cannot suitably explain the differences in the incidence of respiratory diseases among children. A statistically positive correlation can only be observed with $\mathrm{SO}_{2}$.

a) $\mathrm{SIR}^{\star} / \mathrm{PM}_{10}$ (winter average/zimsko povprečje)

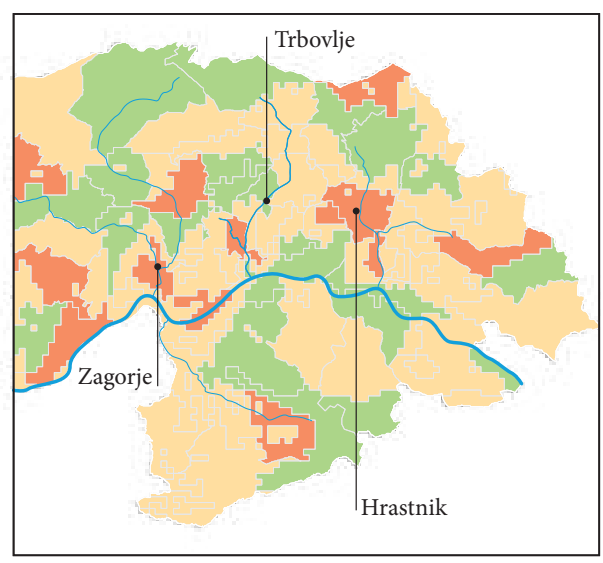

b) $\mathrm{SIR}^{*} / \mathrm{SO}_{2}$ (annual average/letno povprečje)

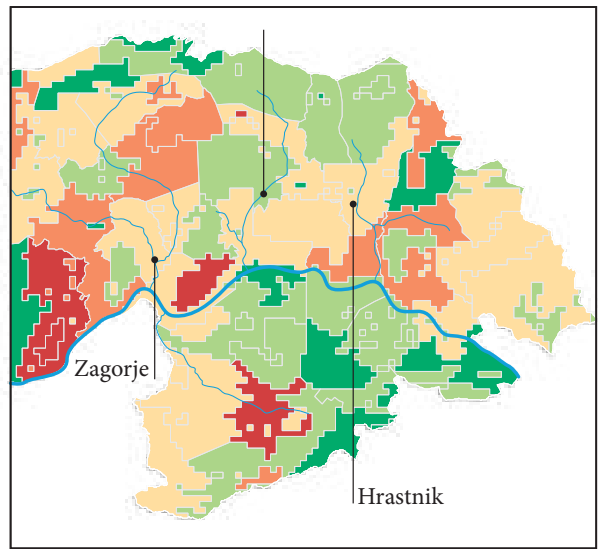

$\square 0-0.490$

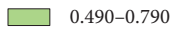

Scale/merilo:

$\begin{array}{lllll}0 & 2.5 & 5 & 7.5 & 10 \mathrm{~km}\end{array}$

1 c) $\mathrm{SIR}^{\star} / \mathrm{PM}_{10}$ (summer average/poletno povprečje)

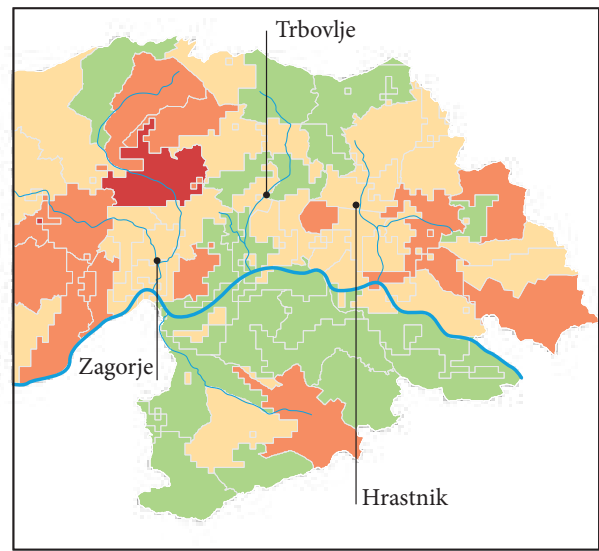

d) $\operatorname{SIR}^{*} / \mathrm{NO}_{2}$ (annual average/letno povprečje)

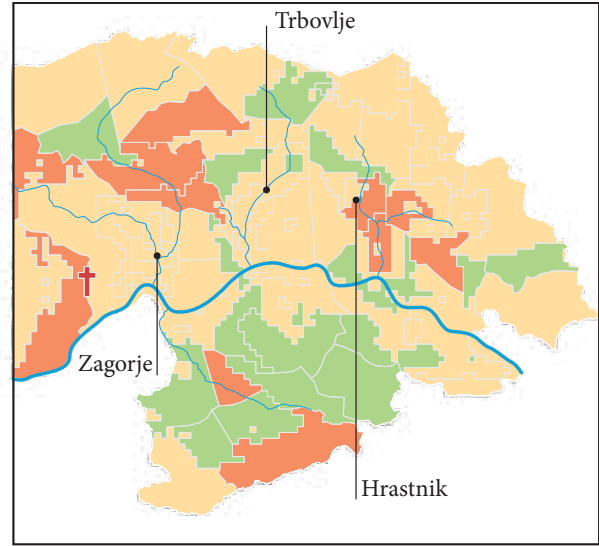

$1.240-1.990$

1.990 and more/in več

Figure 2: Spatial distribution of the spatial component with a conditional autoregressive (CAR) prior probability distribution, 2011. SIR ${ }^{\star}=$ estimated standardized incidence ratio 


\section{Discussion}

The results of this spatial analysis of the correlation between respiratory diseases in children and air pollution showed a statistically significant positive correlation in the effect of the average annual $\mathrm{SO}_{2}$ concentration. In contrast, in other comparable international studies the correlation occurred systematically in areas with increased incidence risk and a high air pollution rate, especially with $\mathrm{PM}_{10}$ and $\mathrm{NO}_{2}$ (Maheswaran et al. 2005; Hu et al. 2008; Beale et al. 2008). In an ecological study of small spatial units, Maheswaran et al. (2005) proved the spatial correlation between $\mathrm{PM}_{10}$ and $\mathrm{NO}_{2}$ and their effects on cardiovascular diseases among people over forty-five. In their ecological study of small spatial units, Hwang

a) $\mathrm{SIR}^{\star}-\mathrm{x} / \mathrm{PM}_{10}$ (winter average/zimsko povprečje)

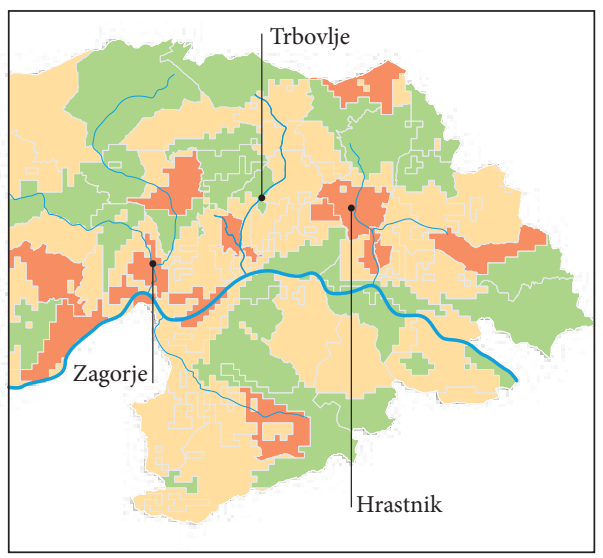

c) $\mathrm{SIR}^{*}-\mathrm{x} / \mathrm{SO}_{2}$ (annual average/letno povprečje)

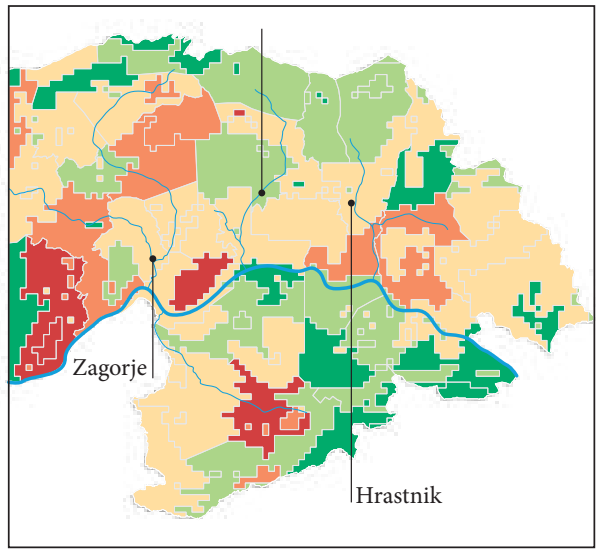

$0-0.490$

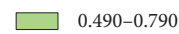

Scale/merilo:

$0 \quad 2.5$
7.5

$10 \mathrm{~km}$ c) $\mathrm{SIR}^{\star}-\mathrm{x} / \mathrm{PM}_{10}$ (summer average/poletno povprečje)

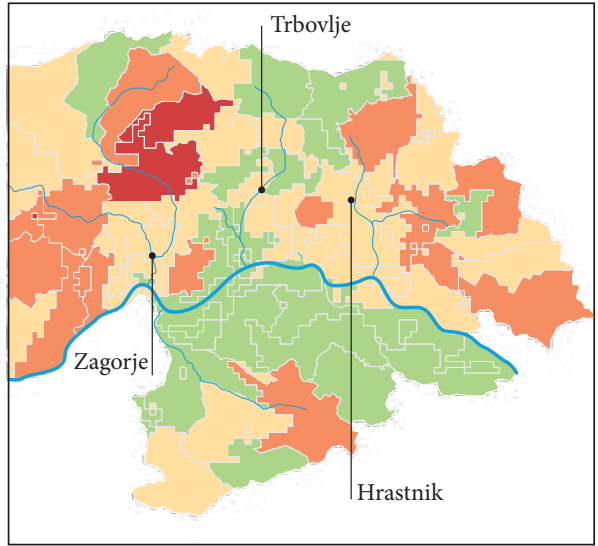

d) $\operatorname{SIR}^{*}-\mathrm{x} / \mathrm{NO}_{2}$ (annual average/letno povprečje)

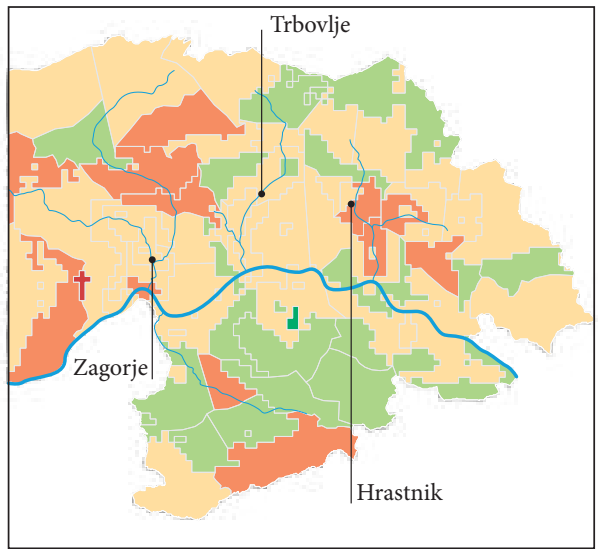

$1.240-1.990$

1.990 and more/in več

Figure 3: Spatial analysis of the correlation between respiratory diseases in children and pollutants by spatial units studied, 2011. SIR*-x=estimated standardized incidence ratio with air pollution included 
and Chan (2001) used Bayesian hierarchical smoothing models to prove the spatial correlation between $\mathrm{PM}_{10}, \mathrm{NO}_{2}, \mathrm{SO}_{2}$, and diseases of the lower respiratory tract.

Based on previous studies in the Central Sava Region, it was expected that a correlation would also be proved in the case of $\mathrm{PM}_{10}$, especially in winter (Kukec et al. 2012, 2013). Nonetheless, based on the results obtained, one cannot conclude that there is no spatial correlation in the Central Sava Region. There were numerous problems with collecting health and environmental data. A number of similar international studies have also drawn attention to the importance of the quality of input environmental and health data (Beale et al. 2008; Stroh et al. 2007).

In analyzing the applicability of health data in this study, it can be established that there were no problems with the completeness of data capture (data for all of the days in the period studied were available at all of the health centers; Kukec et al. 2012). In addition, the analysis did not contain any bias resulting from incorrect geographical distribution of the ill and healthy population. All of the health centers enter the permanent addresses of the ill systematically (from health insurance cards) and so the addresses match the data in the Central Population Registry. However, certain issues were encountered in reviewing the captured data. The first issue appeared in the description of the number of days during which at least one child from an individual municipality in the Central Sava Region visited a doctor at a health center due to a respiratory disease problem. These results were unusual: in the Municipality of Zagorje ob Savi, the reported number of days with at least one child visit due to a problem with any of the selected respiratory diseases was 1.3 to 1.4 times greater than in the municipalities of Trbovlje and Hrastnik. In addition, it was also unusual that in the Municipality of Trbovlje the number of days with at least one child visit due to a problem with any of the selected chronic respiratory diseases was as much as four times greater than in the Municipality of Zagorje ob Savi and 5.8 times greater than in the Municipality of Hrastnik. Of course differences in this indicator can be expected between municipalities, but definitely not to such an extent because the entire Central Sava Region study area is relatively homogenous in terms of demography, socioeconomics, and health (Kukec et al. 2013). It is presumed that the established differences result from the way the health data were recorded (the difference in coding individual diagnoses). Some health centers define certain children's diseases as the respiratory diseases included in this analysis, whereas others code the same diseases as other diseases not included in the analysis. Misclassification may occur due to this (Porta et al. 2008), but it can only affect the results when health data from several health centers are analyzed at the same time. Based on our data, all of the comparable studies to date have been conducted using health data obtained from only one health institution (Šimac 2008; Rems - Novak 2013).

The issue of health data quality could be resolved, but it should be tackled at the national level. The recording of diagnoses in the health-information system should be standardized (detailed instructions for recording should be produced), and the importance of using the International Classification of Diseases (WHO 2011) and of correctly coding diseases under this classification should be given attention when educating young doctors.

\section{Conclusion}

It can be concluded that a statistically significant positive correlation can only be observed in the effect of the average annual $\mathrm{SO}_{2}$ concentration. There is suitable expertise in the use of spatial methods of aggregating environmental and health data, but problems exist with regard to the applicability of the data that are being continuously collected in both information systems (i.e., the health and the environmental systems). By eliminating these deficiencies, studies of comprehensive environmental and health data aggregation could be conducted more often in Slovenia and used to develop evidence-based health policies.

\section{Acknowledgements}

The authors would like to thank the Slovenian Research Agency and Ministry of Health for financially supporting the V3-1049, L1-2082, and L1-4154 projects, as well as members of both project teams. We would also like to thank the staff at the health centers for preparing and providing the health data, and companies for allowing us to use their emission data. 


\section{References}

Beale, L., Abellan, J. J., Hodgson, S., Jarup, L. 2008: Methodologic issues and approaches to spatial epidemiology. Environmental health perspectives 116-8. DOI: http://dx.doi.org/10.1289/ehp.10816

Briggs, D., Corvalan, C., Nurminen, M. 1996: Linkage methods for environment and health analysis, general guidelines. World health organization, Office of global and integrated environmental health. Geneva.

Dos Santos Silva, I. 1999: Cancer epidemiology: principles and methods. Lyon.

Dummer, T. J. B. 2008: Health geography: supporting public health policy and planning. CMAJ 178-9. DOI: http://dx.doi.org/10.1503/cmaj.071783

Eitan, O., Yuval, B., Barchana, M., Dubnov, J., Linn, S., Carmel, Y., Broday, D. M. 2010: Spatial analysis of air pollution and cancer incidence rates in Haifa Bay, Israel. Science of the total environment 408-20. DOI: http://dx.doi.org/10.1016/j.scitotenv.2010.06.031

Elliott, P., Wakefield, J., Best, N., Briggs, D. 2000: Spatial epidemiology. Methods and applications. New York.

Erlih, S., Eržen, I. 2010: Geografski vzorci pojavljanja bolezni dihalnih poti otrok v občini Koper. Zdravstveno varstvo 49-1.

Hu, Z., Liebens, J., Rao, K. R. 2008: Linking stroke mortality with air pollution, income, and greenness in northwest Florida: an ecological geographical study. International journal of health geographics 7-20. DOI: http://dx.doi.org/10.1186/1476-072X-7-20

Hwang, J. S., Chan, C. C. 2001: Effects of air pollution on daily clinic visits for lower respiratory tract illness. American journal of epidemiology 155-1.

Kukec, A., Farkas, J., Erzen, I., Zaletel - Kragelj, L. 2013: A prevalence study on outdoor air pollution and respiratory diseases in children in Zasavje, Slovenia, as a lever to trigger evidence-based environmental health activities. Arhiv za higijenu rada i toksikologiju 64.

Kukec, A., Zaletel - Kragelj, L., Bizjak, M., Poljšak, B., Jereb, G., Fink, R., Zadnik, V., Močnik, G., Košnik, M., Farkaš - Lainščak, J. 2012: Študija celostnega sklapljanja zdravstvenih in okoljskih podatkov v Zasavju kot model študije za podporo pri oblikovanju in izvajanju medsektorskih politik s področja okolja in zdravja, končno poročilo 161. Univerza v Ljubljani, Medicinska fakulteta, Ljubljana.

Maheswaran, R., Haining, R. P., Brindley, P., Law, J., Pearson, T., Fryers, P. R., Wise, S., Campbell, M. J. 2005: Outdoor air pollution, mortality, and hospital admissions from coronary heart disease in Sheffield, UK: a small-area level ecological study. European heart journal 26-23. DOI: http://dx.doi.org/10.1093/ eurheartj/ehi457

MEIS. 2012: Prognostični in diagnostični modelirni sistem za kontrolo onesnaženja ozračja v Regiji (Kooreg Zasavje). Internet: http://www.kvalitetazraka.si/zasavje (15.6.2012).

Morgenstern, H., Thomas, D. 1993: Principles of study design in environmental epidemiology. Environmental health perspectives 101-4.

Porta, M., Greenland, S., Last, J. M. 2008: A dictionary of epidemiology. New York.

Rems - Novak, M. M. 2013: Effects of air pollution with ozone on primary health care consultations for respiratory tract disease in children in Koper Municipality. Magistrsko delo. Univerza v Novi Gorici, podiplomski študij Znanosti o okolju. Nova Gorica.

Rytkönen, M. J.P. 2004: Not all maps are equal: gis and spatial analysis in epidemiology. International journal of circumpolar health 63-1.

Staut, M. 2008: Od medicinske geografije h geografiji zdravja: razvoj veje in slovenske perspektive. Geografski vestnik 80-1.

Stroh, E., Harrie, L., Gustafsson, S. 2007: A study of spatial resolution in pollution exposure modelling. International journal of health geography 6-19. DOI: http://dx.doi.org/10.1186\%2F1476-072X-6-19

Svetovna zdravstvena organizacija. 2011: International classification of diseases - ICD. Internet: http://www.who.int/classifications/icd/en/ (20.7.2011).

Šimac, N. 2008: Onesnaženost zraka z ozonom na Goriškem - ocena vplivov na zdravje ljudi. Specialistična naloga s področja javnega zdravja. Nova Gorica.

Thomas, D. C. 2009: Statistical methods in environmental epidemiology. New York.

Vudrag, M., Boštjančič, D. 2007: Globalna kemizacija - izziv javnemu zdravju. Zdravstveno varstvo 46.

WHO, Regional Office for Europe. 1999: Disease mapping and risk assessment for public health decision-making. Copenhagen.

Zadnik, V. 2006: Geografska analiza vpliva socialno-ekonomskih dejavnikov na incidenco raka v Sloveniji v obdobju 1995-2002. Doktorsko delo. Univerza v Ljubljani, Medicinska fakulteta. Ljubljana.

Zadnik,V., Reich, B. J. 2006: Analysis of the relationship between socioeconomic factors and stomach cancer incidence in Slovenia. Neoplasma 53. 


\section{Geografija zdravja na primeru Zasavja: Povezovanje podatkov o onesnaženosti ozračja in boleznih dihal}

DOI: http://dx.doi.org/10.3986/AGS54208

UDK: 91:613(497.432)

504.5:502.3:616.2(497.432)

COBISS: 1.01

IZVLEČEK: Namen raziskave je bil na primeru Zasavja oceniti povezanost med onesnaženostjo ozračja in boleznimi dihal pri otrocih na ravni majhnih proučevanih prostorskih enot. Zdravstvene in okoljske podatke smo pridobili za obdobje od 1.1.2011 do 31.12.2011. Proučevane prostorske enote smo oblikovali na podlagi ocenjene stopnje onesnaženosti ozračja ter digitalnih zemljevidov mej krajevnih skupnosti in naselij. Vpliv onesnaženosti ozračja na pojavljanje bolezni dihal smo ocenjevali z Bayesovimi modeli. Z odpravo pomanjkljivosti bi predstavljeno metodologijo lahko pogosteje uporabljali pri opredeljevanju območij z večjim zdravstvenim tveganjem.

KLJUČNE BESEDE: majhne proučevane prostorske enote, bolezni dihal, otroci, onesnaženost ozračja, prostorsko glajenje, Zasavje

Uredništvo je prispevek prejelo 31. januarja 2013.

NASLOVI:

Andreja Kukec

Univerza v Ljubljani, Medicinska fakulteta

Center za javno zdravje

Zaloška ulica 4, SI - 1000 Ljubljana, Slovenija

E-pošta: andreja.kukec@mf.uni-lj.si

dr. Lijana Zaletel - Kragelj

Univerza v Ljubljani, Medicinska fakulteta

Center za javno zdravje

Zaloška ulica 4, SI - 1000 Ljubljana, Slovenija

E-pošta:lijana.kragelj@mf.uni-lj.si

dr. Jerneja Farkaš - Lainščak

Univerza v Ljubljani, Medicinska fakulteta

Center za javno zdravje

Zaloška ulica 4, SI - 1000 Ljubljana, Slovenija

E-pošta: jerneja.farkas@mf.uni-lj.si

\section{dr. Ivan Eržen}

Univerza v Ljubljani, Medicinska fakulteta

Center za javno zdravje

Zaloška ulica 4, SI - 1000 Ljubljana, Slovenija

E-pošta: ivan.erzen@mf.uni-lj.si

Andrej Herakovič

Občina Škocjan

Škocjan 67, SI - 8275 Škocjan, Slovenija

E-pošta: andrej.herakovic@obcina-skocjan.si 


\section{dr. Marija Zlata - Božnar}

MEIS storitve za okolje, d. o. o.

Mali Vrh pri Šmarju 78, SI - 1293 Šmarje-Sap, Slovenija

E-pošta: marija.zlata.boznar@meis.si

\section{dr. Primož Mlakar}

MEIS storitve za okolje, d. o. o.

Mali Vrh pri Šmarju 78, SI - 1293 Šmarje-Sap, Slovenija

E-pošta: primoz.mlakar@meis.si

\section{dr. Boštjan Grašič}

MEIS storitve za okolje, d. o. o.

Mali Vrh pri Šmarju 78, SI - 1293 Šmarje-Sap, Slovenija

E-pošta: bostjan.grasic@meis.si

\section{dr. Vesna Zadnik}

Onkološki inštitut Ljubljana

Epidemiologija in register raka

Zaloška cesta 2, SI - 1000 Ljubljana, Slovenija

E-pošta:vzadnik@onko-i.si 


\section{Uvod}

Zaradi prisotnosti in zaznavanja dejavnikov tveganja v naravnem in družbenem okolju ter njihovih vlivov na zdravje geografija zdravja oziroma prostorska epidemiologija vedno bolj pridobiva na pomenu (Zadnik 2006; Staut 2008). Na njeno uporabnost pri oceni in obvladovanju dejavnikov tveganja opozarja tudi Svetovna zdravstvena organizacija (SZO) (Briggs in ostali 1996).

Vpliv okoljskih tveganj je večinoma kompleksen, zato je potrebno pri analizi povezanosti teh pojavov z zdravstvenimi združevati metode javnega zdravja in geografskih informacijskih sistemov (GIS) (SZO 1999; Rytkönen 2004; Vudrag in Boštjančič 2007; Beale in ostali 2008; Dummer 2008; Staut 2008; Erlih in Eržen 2010). S temi metodami lahko opredelimo območja z večjim oziroma manjšim tveganjem za nastanek zdravstvenih pojavov ter jih prikažemo v obliki zemljevidov bolezni (Zadnik 2006).

Eno pomembnejših metodoloških vprašanj v prostorski epidemiologiji je, kakšne in kako velike prostorske enote naj uporabimo kot osnovne enote opazovanja. Najprej se je uporabljalo večje prostorske enote, $\mathrm{z}$ razvojem metod in tehnik prostorske epidemiologije pa se je začelo upora

bljati manjše (Stroh in ostali 2007). Majhne prostorske enote imajo pred velikimi številne prednosti. $\mathrm{Z}$ izbiro manjše osnovne prostorske enote za analizo povečamo ločljivost in na ta način zadržimo informacijo o heterogenosti, ki se pri velikih prostorskih enotah izgubi. Vendar pa so tudi pri uporabi majhnih prostorskih enot prisotni problemi. Eden pomembnejših je, da imamo zaradi manjšanja območja opazovanja tudi vedno manjše število enot za izračun kazalnikov zdravja za posamezno prostorsko enoto, $s$ tem pa se poveča problem nezaupanja vanje (Zadnik 2006; Zadnik in Reich 2006). To nezaupanje pa lahko zmanjšamo. Ena izmed možnosti je, da podaljšamo obdobje opazovanja in s tem povečamo število osnovnih enot za izračun kazalnikov zdravja. Z razvojem prostorske epidemiologije so se pojavile tudi t.i. tehnike prostorskega glajenja, s pomočjo katerih na podlagi dejanskih podatkov in dodanih informacij ocenimo vrednost kazalnika opazovanega zdravstvenega izida za posamezno opazovano prostorsko enoto (Zadnik 2006).

Namen raziskave je bil na primeru Zasavja oceniti povezanost med onesnaženostjo ozračja in boleznimi dihal pri otrocih na ravni majhnih proučevanih prostorskih enot. Cilja raziskave sta bila oceniti pojavnost bolezni dihal pri otrocih in povezanost $z$ onesnaženostjo ozračja na majhnih proučevanih prostorskih enotah. Dodaten cilj je bil oceniti prednosti in pomanjkljivosti takšnega povezovanja.

\section{Metode}

\subsection{Zasnova raziskave}

Raziskava je bila del večjega projekta, ki smo ga izvedli na Katedri za javno zdravje Medicinske fakultete Univerze v Ljubljani ob sodelovanju strokovnjakov zdravstvene in okoljske stroke za obdobje 1.1.2006 do 31. 12. 2011. Po zasnovi je predstavljena raziskava v prvem delu študija prostorskih vzorcev okoljskih in zdravstvenih pojavov, $\mathrm{v}$ drugem delu pa študija prostorske variabilnosti (Morgenstern in Thomas 1993; Thomas 2009).

\subsection{Opazovana populacija in obdobje opazovanja}

Opazovana populacija so bili otroci, stari od enega do enajst let, ki so imeli v obdobju opazovanja stalno prebivališče v eni od treh občin v Zasavju (Zagorje ob Savi, Trbovlje, Hrastnik) in so bili med 1.1.2011 in 31. 12.2011 obravnavani v enem od zasavskih zdravstvenih domov zaradi bolezni dihal.

\subsection{Območje opazovanja}

Kot modelno območje so nam služile oblikovane majhne proučevane prostorske enote. Za vsako od opazo-

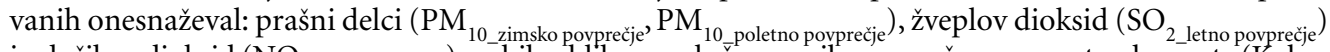
in dušikov dioksid $\left(\mathrm{NO}_{2 \_ \text {letno povprečje }}\right)$, so bile oblikovane ločene majhne proučevane prostorske enote (Kukec in ostali 2012). 


\subsection{Oblikovanje majhnih proučevanih prostorskih enot}

Majhne proučevane prostorske enote so bile oblikovane na podlagi ocenjene stopnje onesnaženosti ozračja ter digitalnih zemljevidov mej krajevnih skupnosti in naselij občin v Zasavju. Za oceno stopnje onesnaženosti ozračja smo uporabili disperzijske modele $\mathrm{z}$ vhodnimi emisijskimi vrednostmi točkovnih virov onesnaževanja in meteorološkimi podatki ter podatki o obremenjenosti s prometom in lokalnimi kurišči. Z modelom Weather Research and Forecasting (WRF) je bila zaradi prognoze in diagnoze onesnaženosti ozračja razvita lastna napoved vremena. Z meteorološkim predprocesorjem SurfPro in tri-dimenzionalnim (3D) masno konsistentnim vetrovnim modelom Swift je bil izračunan približek 3D polj vetra, temperature in turbulentnosti. Za izračun širjenja onesnaženosti je bil uporabljen numerični Lagrangeev model delcev Spray z Monte Carlo simulacijo. Za oblikovanje majhnih proučevanih prostorskih enot je bilo uporabljeno orodje ArcGIS (MEIS, 2012; Kukec in ostali 2012).

\subsection{Izvor in georeferenciacija zdravstvenih podatkov}

Zdravstveni podatki so bili pridobljeni iz zdravstveno informacijskega sistema zdravstvenih domov v Zasavju. Opazovane so bile izbrane diagnoze bolezni dihal po Mednarodni klasifikaciji bolezni, poškodb in vzrokov smrti verzija 10 (MKB-10) (SZO 2011).

Pooblaščena oseba $\mathrm{v}$ zdravstveni ustanovi je posredovala naslednje podatke: identifikacijska koda obiska, datum obiska, vrsta obiska, diagnoza ob obisku, datum rojstva, spol in naslov stalnega prebivališča.

Podatke o naslovu stalnega prebivališča smo georeferencirali-s pomočjo šifrantov Registra prostorskih enot smo vsakemu naslovu določili geografsko koordinato, točkovne podatke pa smo retrogradno agregirali v prostorske enote, ki so bile oblikovane (Kukec in ostali 2012).

\subsection{Prostorska razporeditev primerov bolezni dihal}

Število zbolelih v posamezni majhni proučevani prostorski enoti smo primerjali s številom zbolelih, ki bi ga pričakovali glede na podatke o številu otrok starih do 11 let, ki so po podatkih Centralnega registra prebivalcev leta 2011 živeli v tej enoti in glede na stopnjo zbolevanja v celotnem območju opazovanja (Enačba 1). Količnik med opazovanim in pričakovanim številom zbolelih imenujemo standardiziran količnik inicidence (SIR) in je približek relativnemu tveganju bolezni v tej enoti (Dos Santos Silva 1999).

$$
S I R=\frac{O}{E}=\frac{O}{\frac{\sum n \cdot R}{\sum n}}
$$

Enačba 1

SIR $=$ standardiziran količnik incidence

$\mathrm{O}=$ število otrok do 11 let zbolelih $v$ proučevani prostorski enot $i$

$E=$ stevilo pričakovanih zbolelih $v$ proučevani prostorski enoti

$n=$ število otrok starih do 11 let $v$ opazovani populaciji

$R=$ število zbolelih otrok do 11 let na 100.000 v celotnem območju

Ker je število obravnavanih prostorskih enot relativno veliko oziroma ker v posamezni enoti biva relativno malo otrok, ki bi lahko zboleli, je vpliv naključja na vrednosti izračunanih SIR relativno velik. V prostorski analizi epidemioloških podatkov za zmanjšanje vpliva tovrstnega naključja zato uporabljamo hierarhične modele Bayesovega prostorskega glajenja (Elliott in ostali 2000). Z Bayesovimi hierahičnimi modeli s prilagojeno Poissonovo regresijsko enačbo (Enačba 2) ocenimo vrednost kazalnika bremena bolezni za posamezno proučevano prostorsko enoto na podlagi prepletanja dejanskih podatkov $\mathrm{z}$ dodatnimi informacijami, ki so lahko že znane ali pa gre za slučajne vplive. V analizi smo kot dodatne znane informacije uvrstili incidenco bolezni dihal pri otrocih v sosednjih območjih in povprečno incidenco bolezni dihal pri otrocih na celotnem območju opazovanja. Slučajne vplive smo razdelili na prostorsko odvisne in neodvisne. Prostorsko odvisnim spremenljivkam smo dodelili pogojno avtoregresivno (CAR) apriorno verjetnostno porazdelitev, ki zajame vse podatke o geografski strukturi opazovanega območja. 


$$
S I R^{*}=a+\beta X+H+S
$$

$S I R^{\star}=$ ocenjeni standardiziran količnik incidence

$a=$ osnovno (logaritmirano) relativno tveganje bolezni v celotnem območju opazovanja

$\beta=$ regresijski koeficient pojasnjevalne spremenljivke

$X=$ vrednosti pojasnjevalne spremenlivive

$H=$ prostorsko neodvisen slučajni vpliv

$S=$ prostorsko odvisen slučajni vpliv

\subsection{Ugotavljanje vpliva onesnaženosti ozračja na pojavljanje bolezni dihal}

Pri določanju vpliva onesnaženosti ozračja na pojavljanje bolezni dihal smo v osnovni Bayesov model (Enačba 2) dodali podatke za vsako opazovano onesnaževalo. Osnovni model smo primerjali z razširjenim in ugotavljali, ali se razširjeni model bolj prilega našim podatkom. Uporabljena mera, ki hkrati povzema prileganje podatkom in kompleksnost modela se imenuje DIC (angl. Deviation Information Criterion); manjši kot je DIC, večjo napovedno moč ima model (Elliott in ostali 2000).

\subsection{Prikaz prostorskega razporejanja zdravstvenega tveganja}

Za grafični prikaz empiričnih in ocenjenih SIR smo uporabili zemljevide z barvno lestvico. Opazovanim enotam $\mathrm{z}$ nizkim tveganjem smo dodelili modro barvo, $\mathrm{z}$ visokim pa rdečo.

Zemljevide smo pripravili z orodjem ArcGIS. Prostorsko porazdelitev povezanosti med boleznimi dihal pri otrocih in onesnaženostjo ozračja smo ocenili vizualno, za numerično določitev prostorske strukture pa smo uporabili, statističen parameter delež prostorske variabilnosti posamezne spremenljivke ( Frac $_{\text {Spatial }}$ ). Če je vrednost deleža prostorske variabilnosti blizu 1, potem prevladuje prostorsko odvisen slučajni vpliv. $\mathrm{V}$ primeru vrednosti blizu 0 pa prevladuje prostorsko neodvisen slučajni vpliv (Eitan in ostali 2010).

\section{Rezultati}

\subsection{Prostorska razporeditev standardiziranega količnika incidence bolezni dihal}

Prostorska razporeditev SIR bolezni dihal po majhnih proučevanih prostorskih enotah glede na opazovano onesnaževalo je predstavljena na Sliki $1 . \mathrm{Za} \mathrm{PM}_{10}$ sta prikazani vrednosti za zimsko in poletno povprečje, medtem ko sta za $\mathrm{SO}_{2}$ in $\mathrm{NO}_{2}$ prikazani letni povprečni vrednosti. Opazimo lahko velike razlike v tveganju bolezni dihal pri geografsko sosednjih enotah.

\subsection{Prostorska razporeditev zglajenega standardiziranega količnika incidence bolezni dihal}

Prostorska razporeditev ocen tveganja zbolevanja, ki so bile pripravljene s prostorskim glajenjem v Bayse-ovem hierahičnem modelu, $\mathrm{z}$ upoštevanjem tveganja zbolevanja prebivalstva celotnega območja in tveganje neposrednih sosednjih območij po določenih prostorskih enotah glede na opazovano onesnaževalo, je predstavljena na Sliki 2. Razlike med posameznimi med seboj sosednjimi geografskimi enotami so bistveno manjše. Najpomembnejši statistični parametri modelov so povzeti v preglednici 1. Prostorski vzorec porazdeljevanja opazovanega zdravstvenega izida se kaže pri modelu, ki obravnava $\mathrm{PM}_{10}$ poleti in $\mathrm{SO}_{2}$.

\subsection{Statistični modeli prostorske analize povezanosti med boleznimi dihal in onesnaženostjo ozračja}

Prostorska analiza povezanosti med boleznimi dihal pri otrocih in opazovanimi onesnaževali je predstavljena na Sliki 3, najpomembnejši statistični parametri modelov pa so povzeti v preglednici 1. Vključitev 
Preglednica 1: Statistični parametri osnovnega modela Bayes-ovega hierarhičnega prostorskega glajenja (CAR) in modela z vključeno onesnaženostjo ozračja (CAR-X) povezanosti med boleznimi dihal pri otrocih in onesnaževali po proučevanih prostorskih enotah, za leto 2011.

\begin{tabular}{llccc}
\hline onesnaževala & model & $\begin{array}{c}\text { informacijski kriterij } \\
\text { odklona }\end{array}$ & $\begin{array}{c}\text { delež prostorske } \\
\text { variabilnosti }\end{array}$ & $\begin{array}{c}\text { regresijski koeficient } \\
(95 \% \text { interval zaupanja) }\end{array}$ \\
\hline $\mathrm{PM}_{10}$ zima $\left(\mu \mathrm{g} / \mathrm{m}^{3}\right)$ & CAR & 445,50 & 0,093 & \\
& CAR-X & 446,20 & 0,109 & $0,07(-0,03 ; 0,18)$ \\
\hline $\mathrm{PM}_{10}$ poletje $\left(\mu \mathrm{g} / \mathrm{m}^{3}\right)$ & CAR & 378,39 & 0,778 & $-0,04(-0,19 ; 0,11)$ \\
& CAR-X & 380,43 & 0,789 & $\mathbf{0 , 2 4}(\mathbf{0 , 0 1 ; 0 , 5 1 )}$ \\
\hline $\mathrm{SO}_{2}\left(\mu \mathrm{g} / \mathrm{m}^{3}\right)$ & CAR & 405,00 & 0,570 & \\
& CAR-X & 406,78 & 0,657 & $0,05(-0,05 ; 0,16)$ \\
\hline $\mathrm{NO}_{2}\left(\mu \mathrm{gg} / \mathrm{m}^{3}\right)$ & CAR & 460,29 & 0,310 & \\
& CAR-X & 457,13 & 0,322 & \\
\hline
\end{tabular}

Legenda: CAR - pogojno avtoregresivna apriorna verjetnostna porazdelitev

pojasnjevalnih spremenljivk ni prinesla bistvenega izboljšanja modela - mere ustreznosti modela so primerljive za model CAR (Slika 2) in CAR-X (Slika 3) pri vseh onesnaževalih. Modeli kažejo, da z razlikami $\mathrm{v}$ onesnaženosti med posameznimi območji ne moremo primerno pojasniti razlik v zbolevanju otrok zaradi bolezni dihal. Pozitivna statistično značilna povezanost se kaže le pri $\mathrm{SO}_{2}$.

Slika 1: Prostorska razporeditev dejanske incidenčne stopnje bolezni dihal pri otrocih po proučevanih prostorskih enotah glede na opazovano onesnaževalo, za leto 2011.

$\mathrm{SIR}^{*}$ - standardiziran količnik incidence.

Glej angleški del prispevka.

Slika 2: Prostorska razporeditev prostorske komponente s pogojno avtoregresivno (CAR) apriorno verjetnostno porazdelitvijo, za leto 2011. $\mathrm{SIR}^{*}$ - ocenjeni standardiziran količnik incidence

Glej angleški del prispevka.

Slika 3: Prostorska analiza povezanosti med boleznimi dihal pri otrocih in onesnaževali po proučevanih prostorskih enotah, za leto 2011. $\mathrm{SIR}^{*}-\mathrm{x}$ - ocenjeni standardiziran količnik incidence z vključeno onesnaženostjo ozračja

Glej angleški del prispevka.

\section{Razprava}

Rezultati predstavljene prostorske analize povezanosti med boleznimi dihal pri otrocih ter onesnaženostjo ozračja so pokazali, da se pozitivna statistično značilna povezanost kaže pri vplivu povprečne letne koncentracije $\mathrm{SO}_{2}$. V nasprotju z nami, se je v primerljivih tujih študijah povezanost pojavljala sistematično med povečanim tveganjem za obolevnost na območjih z visoko stopnjo onesnaženosti ozračja, še zlasti s $\mathrm{PM}_{10}$ in $\mathrm{NO}_{2}$ (Maheswaran in ostali 2005; Hu in ostali 2008; Beale in ostali, 2008). V ekološki študiji majhnih prostorskih enot so Maheswaran in ostali (2005) so dokazali prostorsko povezanost med $\mathrm{PM}_{10}$ ter $\mathrm{NO}_{2}$ ter učinki na bolezni srca in žilja pri populaciji nad 45 let. Hwang in Chan (2001) sta v ekološki študiji majhnih prostorskih enot $\mathrm{z}$ uporabo Bayse-ovih hierahičnih modelov glajenja dokazala prostorsko povezanost med $\mathrm{PM}_{10}, \mathrm{NO}_{2}, \mathrm{SO}_{2}$ ter boleznimi spodnjih dihalnih poti.

$\mathrm{Na}$ podlagi predhodno izvedenih raziskav v Zasavju smo pričakovali, da bomo povezanost dokazali še v primeru $\mathrm{PM}_{10}$, zlasti pozimi (Kukec in ostali 2012, 2013). Kljub temu pa na podlagi dobljenih rezultatov, ne moremo zaključiti, da prostorske povezanosti v Zasavju ni. Tako pri zbiranju zdravstvenih kot pri beleženju okoljskih podatkov so bili namreč prisotni številni problemi. Na pomen kakovosti vhodnih okoljskih in zdravstvenih podatkov so opozorili tudi v številnih podobnih tujih raziskavah (Beale in ostali 2008; Stroh in ostali 2007).

Pri analiziranju uporabnosti zdravstvenih podatkov v naši študiji ugotavljamo, da s popolnostjo zajema podatkov nismo imeli težav ( $v$ vseh zdravstvenih domovih so bili na voljo podatki za vse dni opazovanega 
obdobja) (Kukec in ostali 2012). Prav tako ocenjujemo, da v analizo nismo vnašali pristranosti z napačnim geografskim razvrščanjem zbolelih ali zdrave populacije. Stalni naslovi zbolelih se namreč v vseh zdravstvenih domovih vnašajo sistematično (iz kartice zdravstvenega zavarovanja). Naslov se tako sklada s podatkom, ki je zabeležen v Centralnem registru prebivalstva. Smo pa pri pregledu zajetih podatkov naleteli na določene vsebinske nejasnosti. Prva nejasnost se je pokazala pri opisu števila dni, ko je zaradi bolezni dihal obiskal zdravnika v zdravstvenem domu vsaj en otrok iz posamezne občine v Zasavju. Ti rezultati so pokazali nenavadno sliko - pri otrocih iz občine Zagorje ob Savi smo zaznali 1,3- do 1,4-krat večje število dni z vsaj enim obiskom otrok zaradi katerekoli od izbranih bolezni dihal kot v občini Trbovlje ali občini Hrastnik. Prav tako je nenavadno, da je število dni z vsaj enim obiskom otrok zaradi katerekoli od izbranih kroničnih bolezni dihal v občini Trbovlje celo 4,0-krat večje kot v občini Zagorje ob Savi oziroma 5,8-krat večje kot v občini Hrastnik. Seveda lahko pričakujemo razlike med občinami v tem kazalniku, vendar tako velikih za gotovo ne, saj je celotno opazovano območje Zasavja - z vidika demografskih, socialno-ekonomskih in zdravstvenih vidikov dokaj homogeno (Kukec in ostali 2013). Predpostavljamo, da izvirajo ugotovljene razlike iz načina beleženja zdravstvenih podatkov (razlike v kodiranju posameznih diagnoz). V posameznem zdravstvenem domu opredeljujejo nekatera obolenja pri otrocih kot bolezni dihal, ki smo jih v analizi zajeli, $\mathrm{v}$ drugih zdravstvenih domovih pa enaka obolenja kodirajo kot nekatere druge, $\mathrm{v}$ analizi neupoštevane skupine. Zaradi tega lahko pride do pristranost razvrščanja (angl. misclassification) (Porta in ostali 2008) in na rezultate vpliva le v primerih, ko se hkrati analizira zdravstvene podatke več zdravstvenih domov. Po naših podatkih so bile vse primerljive raziskave do sedaj izvedene z zdravstvenimi podatki pridobljenimi le v eni zdravstveni ustanovi (Šimac 2008; Rems - Novak 2013).

Problem kakovosti zdravstvenih podatkov bi lahko rešili, vendar bi se ga morali lotiti na nacionalni ravni. Potrebno bi bilo poenotiti beleženje diagnoz v zdravstveno-informacijski sistem (izdelati natančna navodila za beleženje), pri vzgoji mladih zdravnikov pa povečati ozaveščenost o pomenu uporabe MKB klasifikacije (Svetovna zdravstvena organizacija 2011) in pomenu pravilnega šifriranja bolezni po tej klasifikaciji.

\section{Sklepi}

Zaključimo lahko, da se pozitivna statistično značilna povezanost kaže le pri vplivu povprečne letne koncentracije $\mathrm{SO}_{2}$. Ugotovili smo, da imamo ustrezna znanja na področju uporabe prostorskih metod povezovanja okoljskih in zdravstvenih podatkov. Težave pa imamo na področju same uporabnosti podatkov, ki se stalno rutinsko zbirajo v obeh informacijskih sistemih - zdravstvenem in okoljskem. Z odpravo teh pomanjkljivosti bi lahko v prihodnosti raziskave celostnega povezovanja okoljskih in zdravstvenih podatkov v Sloveniji pogosteje izvajali in uporabili na področju oblikovanja $\mathrm{z}$ dokazi podprtih politik zdravja.

\section{Zahvala}

Avtorji se zahvaljujemo Javni agenciji za raziskovalno dejavnost RS ter Ministrstvu za zdravje RS za finančno podporo projektov V3-1049, L1-2082 in L1-4154 ter sodelujočim članom obeh projektnih skupin. Zahvala gre tudi odgovornim osebam $\mathrm{v}$ zdravstvenih domovih za pripravo in posredovanje zdravstvenih podatkov in podjetjem, ki so dovolila uporabo njihovih emisijskih podatkov.

\section{Literatura}

Glej angleški del prispevka. 